\title{
Alstroemeria presliana HERB. (ALSTROEMERIACEAE) IN CHILE FROM A CYTOGENETIC PERSPECTIVE
}

\author{
Carlos M. Baeza ${ }^{1 *}$, Otto Schrader ${ }^{2}$, Eduardo Ruiz $^{1}$, and María Negritto ${ }^{1}$
}

\begin{abstract}
A B S T R A C T
Alstroemeria (Alstroemeriaceae) is an endemic genus of South America with two major distribution centers in the continent: Chile and Brazil. In Chile the genus is distributed from the North, near Iquique $\left(20^{\circ} 13^{\prime} \mathrm{S}, 70^{\circ} 09^{\prime} \mathrm{W}\right)$ to the Chilean and Argentine Patagonia ( $53^{\circ} 10^{\prime} \mathrm{S}, 70^{\circ} 54^{\prime} \mathrm{W}$ ). The central zone of Chile presents the highest number of species. A. presliana Herb. grows from Curicó (34⒌ $59^{\prime} \mathrm{S}$, $71^{\circ} 14^{\prime}$ W) to Cautín ( $38^{\circ} 45^{\prime} \mathrm{S}, 72^{\circ} 34^{\prime} \mathrm{W}$ ) in Chile and Neuquén ( $36^{\circ} 50^{\prime}$ S, $71^{\circ} 05^{\prime}$ W), Argentina. A comparative karyotype study was made between a population of $A$. presliana subsp. presliana and a population of $A$. presliana subsp. australis Ehr. Bayer. Both populations presented asymmetric karyotypes, with $2 n=2 x=16$ chromosomes, but with different chromosome formulae: $A$. presliana subsp. presliana has a haploid formula with $4 \mathrm{~m}+1 \mathrm{sm}$-sat +1 st-sat +2 t, i.e., four pairs of metacentric chromosomes, one submetacentric pair with satellite, one subtelocentric pair with satellite, and two telocentric pairs. A. presliana subsp. australis has a formula with $2 \mathrm{~m}+1 \mathrm{~m}$-sat $+1 \mathrm{sm}+4 \mathrm{t}$ chromosomes, i.e., two pairs of metacentric chromosomes, one metacentric pair with satellite, one submetacentric pair, and four telocentric chromosomes. These results indicated that the karyotype of the subspecies is very different, and it would be possible to recognize $A$. presliana subsp. australis as a new species.
\end{abstract}

Kew words: Alstroemeriaceae, karyotype, chromosome numbers, Chile.

\section{INTRODUCTION}

Alstroemeria is a South American genus of Alstroemeriaceae that includes around 50 species found from Brazil to the Patagonian Region of Argentina and Chile, in highly diverse habitats ranging from sea level to 4000 m altitude (Bayer, 1987; Ravenna, 1988; Sanso, 2002; Aagesen and Sanso, 2003). Central Chile is recognized as a center of diversity of the genus (Bayer, 1987), with satellite distribution in central and eastern Brazil. Approximately 32 species grow in Chile (Bayer, 1987; Muñoz and Moreira, 2003) and are found between $20^{\circ}$ and $53^{\circ} \mathrm{S}$ lat, with the major number of taxa between $28^{\circ}$ and $37^{\circ} \mathrm{S}$ (Muñoz and Moreira, 2003).

The Chilean species of Alstroemeria have acquired worldwide importance as ornamental plants, due to the beauty of their flowers (Buitendijk et al., 1997). Many of the species have acquired considerable commercial value and they are cultivated in different countries, i.e., Holland, Great Britain, Japan and the USA (Baeza et al., 2007a). The main factors for this attention are the harvest durability of the flowers and the attractiveness of the perigonium. There are new cultivars, such as the hybrid of Alstroemeria, which are produced by controlled hybridization, mutations and artificial selection (Sanso, 2002).

Alstroemeria presliana Herb. subsp. presliana has a very restricted distribution in the Andes, from Curicó $\left(35^{\circ} 27^{\prime} \mathrm{S}\right.$ lat) to Antuco $\left(37^{\circ} 25^{\prime} \mathrm{S}\right.$ lat), from 1500 to $2000 \mathrm{~m}$ of altitude. It is also present in Neuquén Province ( $36^{\circ} 50^{\prime} \mathrm{S}, 71^{\circ} 05^{\prime} \mathrm{W}$ ) in Argentina. On the other hand, A. presliana Herb. subsp. australis Ehr.

\footnotetext{
${ }^{1}$ Universidad de Concepción, Facultad de Ciencias Naturales y Oceanográficas, Casilla 160-C, Concepción, Chile. E-mail: cbaeza@udec.cl *Corresponding author.

${ }^{2}$ Federal Centre for Breeding Research on Cultivated Plants, Institute of Horticultural Crops, Neuer Weg 22/23, 06484 Quedlinburg, Germany. Received: 12 October 2007. Accepted: 24 April 2008.
} 
Bayer only grows in Chile, with a narrow geographic distribution from Curanilahue (37 $23^{\prime}$ S lat) to the South of the Cautín river $\left(38^{\circ} 29^{\prime}\right.$ S lat) from 200 to $1500 \mathrm{~m}$ altitude. (Muñoz and Moreira, 2003). These two subspecies have beautiful pink flowers that are basically differentiated by their size and the intensity of the color, as well as their geographic distribution. Without doubt, this species has an enormous potential as an ornamental plant and it is probable that in the future it will be considered an appropriate species for genetic improvement.

The objective of this research was to analyze and compare the morphology, symmetry and size of the chromosomes of A. presliana subsp. australis and $A$. presliana subsp. presliana, with the perspective that the detailed analysis of the chromosomes of related taxa can provide valuable information related to its evolution and their taxonomy (Dimitrova and Greilhuber, 2000).

\section{MATERIALS AND METHODS}

\section{Vegetal material}

A. presliana samples were collected in two locations in Chile: Termas de Chillán (36 $54^{\prime} \mathrm{S}, 71^{\circ} 24^{\prime}$ W, 1720 m.a.s.1.), Nuble Province, Bío-Bío Region, 2 January 2003 by C. Baeza No 4192 (A. presliana subsp. presliana), and Piedra del Águila (37 $49^{\prime} \mathrm{S}, 73^{\circ} 08^{\prime}$ W, 1350 m.a.s.l.), Nahuelbuta National Park, Malleco Province, La Araucanía Region, 15 December 2005 by C. Baeza No $4250 \mathrm{c}$ (A. presliana subsp. australis). The material collected was deposited at the Herbarium of the Universidad de Concepción, Concepción, Chile (CONC).

\section{Obtaining karotypes}

Root apexes of 5-10 mm length, obtained from plants grown in greenhouses, were pre-treated with a solution of 8-hydroxyquinoline $(2 \mathrm{mM})$ for $24 \mathrm{~h}$ at $4{ }^{\circ} \mathrm{C}$, then fixed in a solution of ethanol/acetic acid (3:1) for $24 \mathrm{~h}$ and stored at $-20^{\circ} \mathrm{C}$. The root of the population of $A$. presliana subsp. presliana (C. Baeza 4192) were washed twice in distilled water for $10 \mathrm{~min}$ prior to maceration and then were digested in a mixture of enzymes of $4 \%$ cellulase (Onozuka R-10, Serva, Heidelberg, Germany) and $1 \%$ pectolyase Y-23 (Seishin Pharmaceutical, Chiba-Ken, Japan) and 1\% pectolyase Y-23 (Seishin Pharmaceutical, Chiba-Ken, Japan) in $\mathrm{KCl} 75 \mathrm{mM}$, at $\mathrm{pH} 4.0$ for $25 \mathrm{~min}$ at $37^{\circ} \mathrm{C}$. Following a brief washing in distilled water, the roots were placed in acetic acid $45 \%$ for $1 \mathrm{~min}$ and then were squashed on slides. The prepared samples were stored in a freezer at $-84^{\circ} \mathrm{C}$ and after $2 \mathrm{~h}$ the cover glass were taken out. The samples were dried for $24 \mathrm{~h}$ at room temperature and stored at $-20{ }^{\circ} \mathrm{C}$. The chromosomes were dyed with DAPI (1 ng L-1 4', 6-diamidino-2-phenylindole) (Baeza et al., 2007b).

With the population of $A$. presliana subsp. australis (C. Baeza 4250 c), after fixation an acid hydrolysis was done with $\mathrm{HCl} 0.5 \mathrm{~N}$ for $25 \mathrm{~min}$ at $40^{\circ} \mathrm{C}$, samples were washed twice in distilled water and finally the apex of the root was dyed with acetic orcein at $1 \%$ and then squashed. The account and interpretation of the chromosomes (10 metaphasic plates, five individuals) were carried out using an optical microscope (Axioskop Zeiss, Jena, Germany) with a digital camera (Canon PowerShot G6). The chromosomes were measured with the MicroMeasure 3.3 program (Reeves, 2001) and were classified according to arm radius (Levan et al., 1964). The asymmetry of the karyotype (AsI \%) was determined for each species analyzed using the formula of Arano and Saito (1980). The length of each chromosome was calculated as the percentage of the total genomic length of the corresponding set of haploid chromosomes. Corel Draw 8.0 was used to prepare the ideograms and the micro-photographs (1160x) were analyzed and contrasted with the Paint Shop Pro 7 Program.

\section{RESULTS AND DISCUSSION}

The two populations of $A$. presliana studied have an asymmetric karotype with $2 n=2 x=16$ chromosomes (Table 1). A. presliana subsp. presliana has a haploid formula with $4 \mathrm{~m}+1 \mathrm{sm}$-sat +1 st-sat $+2 \mathrm{t}$, that is, four

Table 1. Comparison of karyotype characteristics of Alstroemeria presliana subsp. presliana and A. presliana subsp. australis.

\begin{tabular}{llccc}
\hline \multicolumn{1}{c}{ Species } & 2n & Chromosomal Set & AsI \% & R \\
\hline A. presliana subsp. presliana & 16 & $4 \mathrm{~m}+1 \mathrm{sm}-\mathrm{sat}+1 \mathrm{st}-\mathrm{sat}+2 \mathrm{t}$ & 64.5 & 3.2 \\
A. presliana subsp. australis & 16 & $2 \mathrm{~m}+1 \mathrm{~m}$-sat $+1 \mathrm{sm}+4 \mathrm{t}$ & 70.2 & 2.6 \\
\hline
\end{tabular}

AsI \%: karyotype asymmetry index according to Arano and Saito (1986); R: brachial index. 
pairs of metacentric chromosomes, one submetacentric pair with a satellite, one subtelocentric pair with satellite and two telocentric pairs (Figure 1A, Table 1). $A$. presliana subsp. australis has a $2 \mathrm{~m}+1 \mathrm{~m}$-sat $+1 \mathrm{sm}+$ $4 \mathrm{t}$ haploid formula, which is three pairs of metacentric chromosomes, pair 2 with a satellite, one submetacentric pair and four pairs of telocentric chromosomes (Figure $1 \mathrm{~B}$, Table 1$)$. The values of the asymmetry index of the karotype (AsI \%) and brachial index (R, coefficient between the greater and lesser chromosome pair) (Baeza et al., 2007a) for each subspecies is summarized in Table 1. Graphic representation (ideogram) of the subspecies can be seen in Figure 2. The chromosome sizes of A. presliana subsp. presliana and A. presliana subsp. australis are summarized in Tables 2 and 3, respectively.

Alstroemeria is a genus with great diversity in the Mediterranean region of central Chile. A high number of species and the highest percentage of endemism are concentrated in this region (Muñoz and Moreira, 2003). Both subspecies of A. presliana are found in this area. Based on collected material in the Nahuelbuta, Bayer (1987) described the subspecies australis in the Nahuelbuta mountain range, in the Araucanía Region of Chile. In addition to their distinct distribution, the
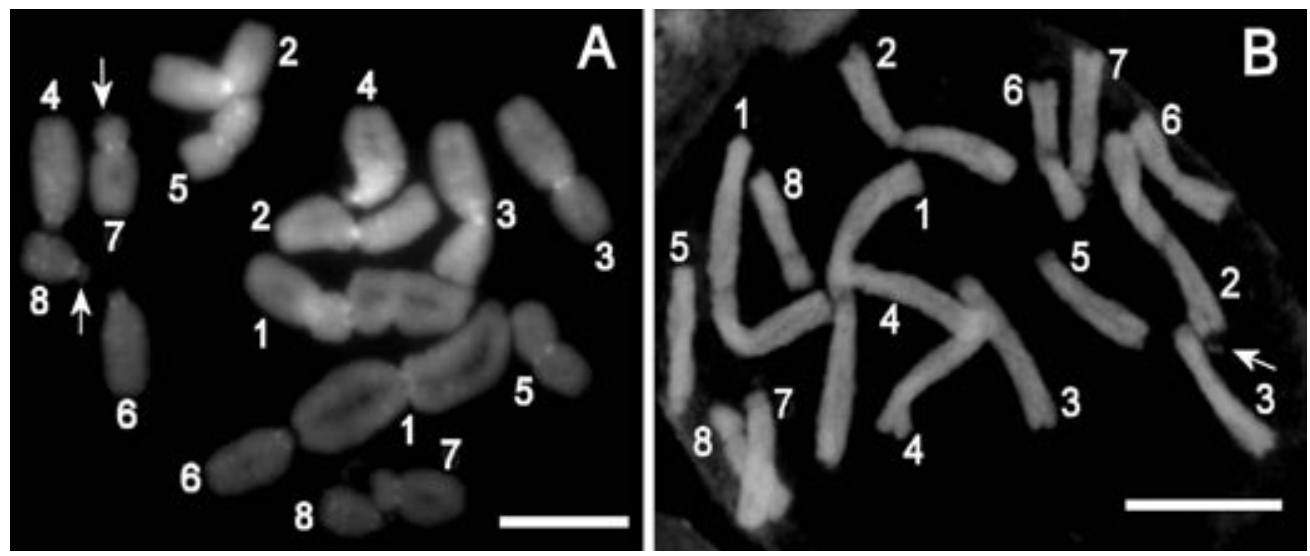

Figure 1. Metaphase plate of (A) Alstroemeria presliana subsp.presliana, Nevados de Chillán (Baeza 4192$)$, (B) A. presliana subsp. australis, Parque Nacional Nahuelbuta (Baeza 4250 c).

Arrows indicate the positions of satellites. Scale bar $=10 \mu \mathrm{m}$.
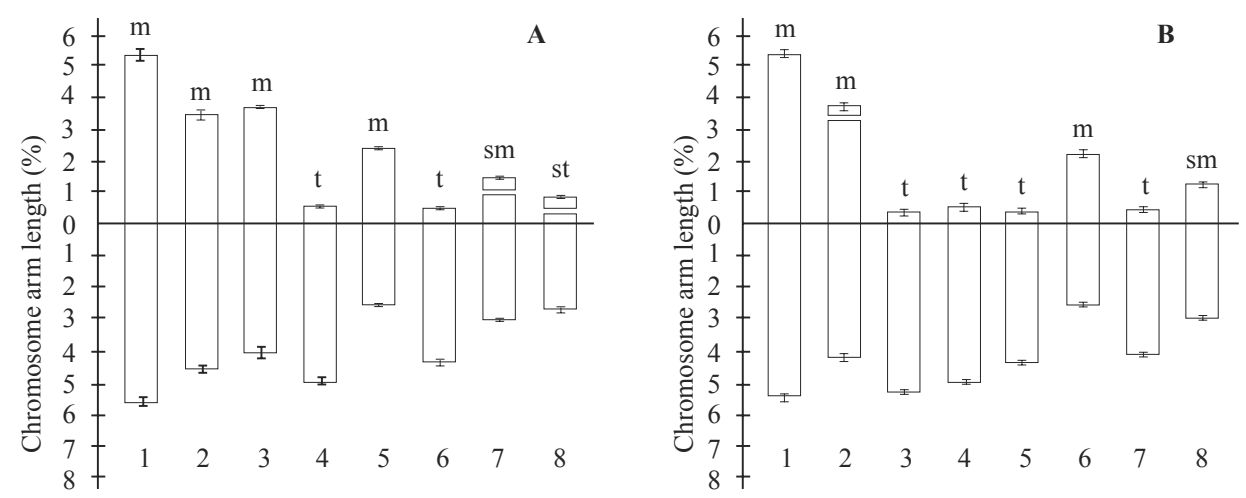

$\mathbf{m}=$ metacentric $; \mathbf{s m}=$ submetacebtric $; \mathbf{s t}=$ subtelocentric $; \mathbf{t}=$ telocentric.

Figure 2. Haploid ideogram of (A) Alstroemeria presliana subsp. presliana, Nevados de Chillán (Baeza 4192), (B) A. presliana subsp. australis, Parque Nacional Nahuelbuta (Baeza 4250 c).

Chromosomes have been ordered in decreasing size. 
size and the more intense pink coloring of the flowers distinguishes subsp. australis from the typical subspecies (Bayer 1987; Muñoz and Moreira, 2003), which have a broader distribution in Chile and Argentina (Neuquén).

There are many works related to chromosome studies in Alstroemeria species (De Jeu et al., 1997; Kamstra et al., 1997; Kuipers et al., 1997; Buitendijk et al., 1998; Kuipers et al., 1998; Sanso and Hunziker, 1998; Kuipers et al., 2002; Sanso, 2002; Zhou et al., 2003; Jara et al., 2004; Baeza et al., 2006; 2007a; 2007b). Based on this evidence it is possible to establish that there is a high degree of stability in terms of the number of diploid chromosomes $(2 n=16)$, the absence of natural polyploids and the presence of groups in accordance to the morphology of the first three pairs of chromosomes (the larger ones). So, it is possible to recognize the following species groups: A. graminea Phil., A. magnifica Herb. (one pair of metacentric chromosomes), A. andina Phil. var. venustula (Phil.) M. Muñoz, A. aurea Graham, A. angustifolia Herb., A. peregrina L., A. philippii Baker (two pairs of metacentric chromosomes) and $A$. ligtu L. subsp. ligtu and $A$. ligtu L. subsp. simsii (Sprengel) Bayer (three pairs of metacentric chromosomes).

Table 2. Average length of chromosomes of Alstroemeria presliana subsp. presliana (Baeza 4192). Mean length calculated as percentage of haploid genome length of $\mathbf{1 0}$ metaphases.

\begin{tabular}{ccccccc}
\hline $\begin{array}{c}\text { Chromosome } \\
\text { pair }\end{array}$ & $\begin{array}{c}\text { Long arm } \\
\text { length }\end{array}$ & \multicolumn{2}{c}{ Short arm length } & $\begin{array}{c}\text { Total relative } \\
\text { length }\end{array}$ & $\begin{array}{c}\text { Total absolute } \\
\text { length }\end{array}$ & $\begin{array}{c}\text { R } \\
\text { Chromosome } \\
\text { type }\end{array}$ \\
\hline \multicolumn{2}{c}{$\mathbf{( \% )} \pm$ SD } & $\%$ & $\boldsymbol{\mu m}$ & & \\
1 & $5.64 \pm 0.22$ & $5.31 \pm 0.32$ & 10.95 & 21.72 & 1.06 & $\mathrm{~m}$ \\
2 & $4.63 \pm 0.20$ & $3.41 \pm 0.26$ & 8.04 & 15.95 & 1.36 & $\mathrm{~m}$ \\
3 & $4.11 \pm 0.35$ & $3.60 \pm 0.10$ & 7.71 & 15.29 & 1.14 & $\mathrm{~m}$ \\
4 & $5.00 \pm 0.17$ & $0.56 \pm 0.10$ & 5.56 & 11.03 & 8.93 & $\mathrm{t}$ \\
5 & $2.61 \pm 0.10$ & $2.35 \pm 0.10$ & 4.96 & 9.84 & 1.11 & $\mathrm{~m}$ \\
6 & $4.41 \pm 0.20$ & $0.49 \pm 0.10$ & 4.90 & 9.72 & 9.00 & $\mathrm{t}$ \\
7 & $3.08 \pm 0.14$ & $1.37 \pm 0.22$ & 4.45 & 8.83 & 2.25 & sm-sat \\
8 & $2.76 \pm 0.17$ & $0.68 \pm 0.17$ & 3.44 & 6.82 & 4.06 & st-sat \\
\hline
\end{tabular}

SD: standard deviation; R: brachial index; m: metacentric; sm-sat: submetacentric with satellite; st-sat: subtelocentric with satellite; t: telocentric.

Table 3. Average length of chromosomes of Alstroemeria presliana subsp. australis (Baeza 4250 c). Calculated as a percentage of mean haploid genome length of 10 metaphases.

\begin{tabular}{|c|c|c|c|c|c|c|}
\hline $\begin{array}{c}\text { Chromosome } \\
\text { pair }\end{array}$ & $\begin{array}{c}\text { Long arm } \\
\text { length }\end{array}$ & Short arm length & $\begin{array}{c}\text { Total relative } \\
\text { length }\end{array}$ & $\begin{array}{c}\text { Total absolute } \\
\text { length }\end{array}$ & $\mathbf{R}$ & $\begin{array}{c}\text { Chromosome } \\
\text { type }\end{array}$ \\
\hline & \multicolumn{2}{|c|}{$(\%) \pm \mathrm{SD}$} & $\%$ & $\mu \mathrm{m}$ & & \\
\hline 1 & $5.59 \pm 0.20$ & $5.53 \pm 0.20$ & 11.19 & 20.00 & 1.01 & $\mathrm{~m}$ \\
\hline 2 & $4.35 \pm 0.25$ & $3.83 \pm 0.25$ & 8.18 & 14.62 & 1.14 & m-sat \\
\hline 3 & $5.44 \pm 0.10$ & $0.41 \pm 0.15$ & 5.85 & 10.46 & 13.27 & $\mathrm{t}$ \\
\hline 4 & $5.18 \pm 0.20$ & $0.56 \pm 0.15$ & 5.74 & 10.26 & 9.25 & $\mathrm{t}$ \\
\hline 5 & $4.53 \pm 0.15$ & $0.47 \pm 0.15$ & 5.00 & 8.94 & 9.63 & $\mathrm{t}$ \\
\hline 6 & $2.64 \pm 0.25$ & $2.28 \pm 0.25$ & 4.92 & 8.79 & 1.16 & $\mathrm{~m}$ \\
\hline 7 & $4.23 \pm 0.20$ & $0.47 \pm 0.15$ & 4.70 & 8.40 & 9.00 & $\mathrm{t}$ \\
\hline 8 & $3.11 \pm 0.10$ & $1.25 \pm 0.10$ & 4.36 & 7.79 & 2.45 & $\mathrm{sm}$ \\
\hline
\end{tabular}

SD: standard deviation; R: índice braquial; m: metacentric; m-sat: metacentric with satellite; sm: submetacentric; t: telocentric. 
A particular case is A. hookeri Lodd. subsp. hookeri, where populations-groups have two pairs of metacentric chromosomes and three pairs of metacentric chromosomes. But the groups are geographically separated by several kilometers (Baeza et al., 2007b). The same situation was observed in the analyzed subspecies of $A$. presliana. Comparing the first three pairs of chromosomes, differences were noted in terms of morphology. The chromosome 3 in subspecies presliana is metacentric and in the subspecies australis it is telocentric. Therefore asymmetry index of the karyotype (AsI \%) in the subspecies presliana is much lower than in the subspecies australis, indicating that the subspecies australis has a higher number of acrocentric chromosomes. In addition, chromosome 2 of the subspecies australis has a microsatellite in the short arm, which is not observed in subspecies presliana. The position of chromosome 5 (metacentric) in the subspecies presliana could also be located in position 6 , because there is no significant difference between these two chromosomes, which means that the type and position of chromosomes 5 and 6 would be identical in both subspecies. Microsatellites are clearly present in chromosomes 7 and 8 in the subspecies presliana and are submetacentric and subtelocentric, respectively, while in the subspecies australis they are telocentric and submetacentric without microsatellites. With regard to the chromosome size (Tables 2 and 3 ) it was observed that in A. presliana subsp. presliana the total value of the haploid length of the chromosomes is $99.2 \mu \mathrm{m}$, while in the subspecies australis it is $89.26 \mu \mathrm{m}$, which indicates a clear difference between them.

It is probable that a more detailed study of the full range of distribution of each subspecies, including material from Argentina, as well as using not only chromosomes studies, but also detailed isozymes, and floral morphological studies could help in defining whether the subspecies australis is a new species in Chile. This result is of great interest given that Alstroemeria represents a genetic resource for our country in genetic improvement programs in different parts of the world such as Holland, USA, Germany and Poland, among others.

\section{CONCLUSIONS}

On the basis of the results obtained from this research it can be concluded that there are clear karyotypic differences, in morphology, symmetry and size of chromosomes among the subspecies of Alstroemeria presliana in Chile.

\section{RESUMEN}

Alstroemeria presliana Herb. (Alstroemeriaceae) M. Baezajo $1 \%$ otto Schrader ${ }^{2}$ Eduardo Ruiz 1 , Negritto $^{1}$. Alstroemeria (Alstroemeriaceae) es un género endémico de Sudamérica y presenta dos grandes centros de distribución: Chile y Brasil. En Chile se distribuye desde el norte, cerca de Iquique $\left(20^{\circ} 13^{\prime}\right.$ S, $70^{\circ} 09^{\prime} \mathrm{O}$ ) hasta la Patagonia ( $\left.53^{\circ} 10^{\prime} \mathrm{S}, 70^{\circ} 54^{\prime} \mathrm{O}\right)$. La zona central del país presenta el mayor número de especies. A. presliana Herb. crece con una distribución que va desde Curicó (34 $59^{\circ} \mathrm{S}, 71^{\circ} 14^{\prime}$ O) a Cautín ( $\left.38^{\circ} 45^{\prime} \mathrm{S}, 72^{\circ} 34^{\prime} \mathrm{O}\right)$ en Chile y en la Provincia de Neuquén ( $\left.36^{\circ} 50^{\prime} \mathrm{S}, 71^{\circ} 05^{\prime} \mathrm{O}\right)$, Argentina. Se hizo un estudio comparativo del cariotipo de $A$. presliana subsp. presliana con A. presliana subsp. australis Ehr. Bayer. Las dos poblaciones presentaron un cariotipo asimétrico, con $2 n=2 x=16$ cromosomas, pero con cromosomas diferentes: A. presliana subsp. presliana presenta una fórmula haploide $4 \mathrm{~m}+1 \mathrm{sm}$-sat +1 st-sat $+2 \mathrm{t}$, esto es, cuatro pares de cromosomas metacéntricos, un par submetacéntrico con satélite, un par subtelocéntrico con satélite y dos pares telocéntricos. En cambio, $A$. presliana subsp. australis tiene una fórmula haploide constituida por $2 \mathrm{~m}+1 \mathrm{~m}$-sat $+1 \mathrm{sm}+4 \mathrm{t}$, esto es, dos pares de cromosomas metacéntricos, un par metacéntrico con satélite, un par submetacéntrico y cuatro pares de cromosomas telocéntricos. Estos resultados evidencian que el cariotipo entre las subespecies es muy diferente, lo que podría estar indicando que la subespecie australis correspondería a una nueva especie dentro del género.

Palabras clave: Alstroemeriaceae, cariotipo, número cromosómico, Chile.

\section{ACKNOWLEDGEMENTS}

We acknowledge the financial support by FONDECYT Project $\mathrm{N}^{\mathrm{o}} 1070520$. As well, we thank the Alexander von Humboldt Foundation (Georg Foster Stipendium) and the Department of Botany of the Universidad of Concepción for facilities. 


\section{LITERATURE CITED}

Aagesen, L., and M. Sanso. 2003. The phylogeny of the Alstroemeriaceae, based on morphology, rps16 Intron, and rbcL sequence data. Syst. Bot. 28:47-69.

Arano, H., and H. Saito. 1980. Cytological studies in family Umbelliferae 5. Karyotypes of seven species in subtribe Seselinae. La Kromosomo 2:471-480.

Baeza, C., O. Schrader, E. Ruiz, and M. Negritto. 2006. Análisis comparativo del cariotipo en poblaciones de Alstroemeria ligtu subsp. ligtu y A. ligtu subsp. simsii (Alstroemeriaceae) de Chile. Darwiniana 44:313-318.

Baeza, C., O. Schrader, E. Ruiz, and M. Negritto. 2007a. Análisis comparativo del cariotipo en poblaciones de Alstroemeria aurea R. Graham (Alstroemeriaceae) de Chile. Gayana Bot. 64:33-39.

Baeza, C., O. Schrader, and H. Budahn. 2007 b. Characterization of geographically isolated accessions in five Alstroemeria L. species (Chile) using FISH of tandemly repeated DNA sequences and RAPD analysis. Plant Syst. Evol. 269:1-14.

Bayer, E. 1987. Die Gattung Alstroemeria in Chile. Mitt. Bot. Staatssamml. (München) 24:1-362.

Buitendijk, J., E. Boon, and M. Ramanna. 1997. Nuclear DNA content in twelve species of Alstroemeria L. and some of their hybrids. Ann. Bot. (London) 79:343-353.

Buitendijk, J., A. Peters, R. Jan-Quené, and M. Ramanna. 1998. Genome size variation and C-band polymorphism in Alstroemeria aurea, A. ligtu and A. magnifica (Alstroemeriaceae). Plant Syst. Evol. 212:87-106.

De Jeu, M., J. Lasschuit, A. Kuipers, S. Kamstra, and R. Visser. 1997. Characterisation and localization of repetitive DNA sequences in the ornamental Alstroemeria aurea Graham. Theor. Appl. Genet. 94:982-990.

Dimitrova, D., and J. Greilhuber. 2000. Karyotype and DNA-content evolution in ten species of Crepis (Asteraceae) distributed in Bulgaria. Bot. J. Linn. Soc. 132:281-297.

Jara, P., C. Palma, and E. Von Brand. 2004. Karyotype and C-bands in the annual inca lily Alstroemeria graminea. Belg. J. Bot. 137:199-204.
Kamstra, S., A. Kuipers, M. De Jeu, M. Ramanna, and E. Jacobsen. 1997. Physical localization of repetitive DNA sequences in Alstroemeria: karyotyping of two species with species-specific and ribosomal DNA. Genome 40:652-658.

Kuipers, A., D. Van Os, H. De Jong, and M. Ramanna. 1997. Molecular cytogenetics of Alstroemeria: identification of parental genomes in interspecific hybrids and characterization of repetitive DNA families in constitutive heterochromatin. Crom. Res. 5:31-39.

Kuipers, A., J. Heslop-Harrison, and E. Jacobsen. 1998. Characterisation and physical localization of Ty1copia-like retrotransposons in four Alstroemeria species. Genome 41:357-367.

Kuipers, A., S. Kamstra, M. De Jeu, and R. Visser. 2002. Molecular characterisation and physical localization of highly repetitive DNA sequences from Brazilian Alstroemeria species. Chrom. Res. 10:389-398.

Levan, A., K. Fredga, and A. Sandberg. 1964. Nomenclature for centromeric position on chromosomes. Hereditas 52:201-220.

Muñoz, M., and A. Moreira. 2003. Alstroemerias de Chile. Diversidad, distribución y conservación. 140 p. Taller La Era, Santiago, Chile.

Ravenna, P. 1988. New or noteworthy species of Alstroemeria. Phytologia 64:281-288.

Reeves, A. 2001. MicroMeasure: a new computer program for the collection and analysis of cytogenetic data. Genome 44:239-443.

Sanso, A. 2002. Chromosome studies in Andean taxa of Alstroemeria (Alstroemeriaceae). Bot. J. Linn. Soc. 138:451-459.

Sanso, A., and J. Hunziker. 1998. Karyological studies in Alstroemeria and Bomarea (Alstroemeriaceae). Hereditas 129:67-74.

Zhou, S., M. De Jeu, R. Visser, and A. Kuipers. 2003. Characterisation of distant Alstroemeria hybrids: application of highly repetitive DNA sequences from A. ligtu subsp. ligtu. Ann. Appl. Biol. 142:277-283. 